\title{
ВИСТИНАТА ЗА ОСИРОМАШЕНИОТ УРАНИУМ
}

\section{Крат̄ка сооржина}

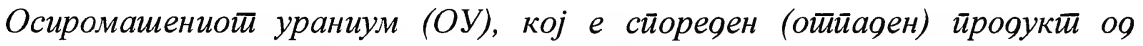
ироцесой на ураниумско зботайување, наоі̆ неколку воени и цивилни иримени. На иростиорийе на Балканой сииана йознай йо нетовайа уйойреба оя сиирана на НАТО-Алијансайа во иниервенцијайа во иооранешна Сојузна Рейублика Југославија како оклой-йробивна мунииија и йо йоооинежните изјави за зоравсиввениие

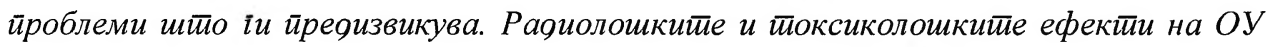
се слични на ефекииите на иррирояниой ураниум кој ойсекогаш бил сеирисуиенн на земјайа. Дояека нивнайа хемиска йоксичносии e иоенииична, вкуйнайа

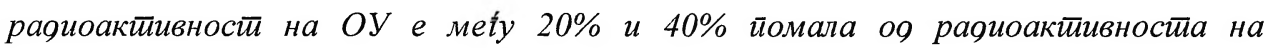

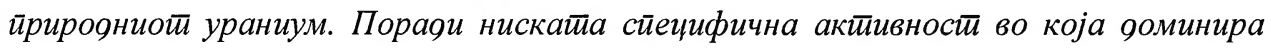
алфа-зрачењетио, на наяворешнайа изложеносй на ОУ не иे се йрийишува акуиенн ризик. Мноіу йоіолема ойасносии йрейсииавува оУ внесен во ителойо, йрея сѐ, йораяи неіовайа слаба расииворливосии. Заіриженосйа околу можнииее йослеяиии врз зоравјетио на луіетио кои живеай на конфликиинииее иростиори каяе шито била уйойребена муничија оя ОУ инииира значајни еколошко-зоравсиивени иррашања

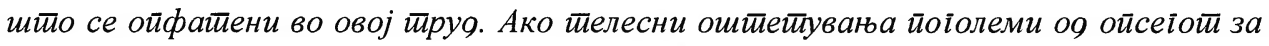
вреяносииите на иррирояниой ураниум се реіистрирани еяинсиввено кај екийажой на возилайа шито биле йотояени оя ОУ-мунииија, се йостиавува йрашањетио яали значајни зоравсиивени ефекиии и ироченииее оя йослеоовайелен ризик оя рак ииреба gа се засноваай на ииеореитски размислувања?! Исииийвањайа укажуваай яека

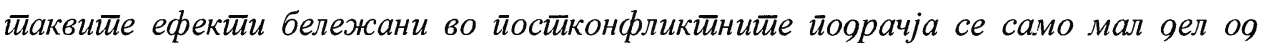
ефекӣитие на ирироонайа раоијачија.

Клучни зборови: ОСИРОМАШЕН УРАНИУМ, ИЗОТОПИ, ВЛИЈАНИЕ, РАДИОАКТИВНОСТ, ТОКСИЧНОСТ, ДОЗА

\section{1. Вовеg}

Природниот ураниум се состои од три изотопи, ураниум-238, ураниум-235 и ураниум-234. Изотопите на елементот, во основа, ги поседуваат истите хемиски и физички карактеристики, бидејќи имаат ист број протони (92) во своите атоми. Единствената разлика помеѓу нив е во бројот на неутроните и токму оваа варијација кај изотопите ги одредува нивните радиолошки особини. Разликата помеѓу изотопите се состои во типовите зрачење што го емитираат изотопите со процесот на нуклеарниот распад, како и разликите во периодот на распадот, интеракцијата со нуклеарните честички и способноста да подложат 
на нуклеарна фисија. Особините на осиромашениот ураниум ја диктираат и неговата апликативна вредност.

\begin{tabular}{|c|c|c|c|}
\hline Табела 1: Изотопска застапеност на ураниум & & \\
\hline Ураниум & & & \\
\hline Природен ураниум & {$[\%]$} & {$[\%]$} & {$[\%]$} \\
\hline Осиромашен ураниум & & & \\
\hline
\end{tabular}

Осиромашениот ураниум е спореден продукт на процесот што се нарекува ураниумско збогатување во кој природниот ураниум (добиен од ураниумска руда) се процесира до форма на збогатен ураниум за потребите на нуклеарните централи. Збогатена форма од ураниум (во која концентрацијата на ураниум-235 е зголемена) е потребна за производство на енергија и во нуклеарни реактори и во нуклеарни оружја. Повеќето цивилни и воени реактори побаруваат ураниум кој има повисок процент на ураниум-235 отколку оној присутен во природниот ураниум. Цивилните нуклеарни централи во САД употребуваат 3-5\% ураниум-235. Нуклеарните оружја употребуваат „високо збогатен ураниум" (ХЕУ-хигхлу енрицхед ураниум) со повеќе од 90 проценти ураниум-235. Некои истражувачки реактори и сите нуклеарни реактори во морнарицата на САД, исто така, користат високо збогатен ураниум.

\begin{tabular}{|c|c|c|}
\hline Изотоп & Природен ураниум & Осиромашен ураниум \\
\hline $\mathrm{y}-234$ & $48,8 \%$ & $15,2 \%$ \\
\hline $\mathrm{y}-235$ & $2,4 \%$ & $1,1 \%$ \\
\hline $\mathrm{y}-238$ & $48,8 \%$ & $83,7 \%$ \\
\hline
\end{tabular}

Останатата ураниумска мешавина (откако е отстранет збогатениот ураниум) има намалена концентрација на ураниум-235 и ураниум-234 и позната е како осиромашен ураниум („ДУ”- во западната терминологија). Типично, осиромашениот ураниум употребен во муниција содржи: ураниум-234 0,001\%; ураниум-235 0,2\%; и ураниум-238 99,8\%. Ако ОУ е делумно добиен од репроцесирано реакторско гориво, тогаш може да содржи и ураниум-236 (приближно) 0,0003\% и трагови количество од плутонум, нептуниум, америциум и фисиони продукти. Бидејќк радиоактивноста на грам од секој ураниумски 
изотоп е различна, соодносот на изотопите во природниот и во осиромашениот е различен доколку тој се изразува преку радиоактивноста од оној преку масата (види Табела 2).

Се поставува прашањето колку, всушност, е радиокативен осиромашениот ураниум (ОУ). ОУ е помалку радиоактивен отколку природниот ураниум бидејќ поседува помалку од оние изотопи што се повеќе радиоактивни, како што се У-234 и У-235, по единица тежина отколку природниот ураниум. Меѓународната агенција за атомска енергија (International Atomic Energy Agency - IAEA) го дефинира ОУ како материја со ниска специфична активност. Специфичната активност (активност во бекерели на единица маса) се користи како мерка за да се докаже колку е нешто радиактивно. Активност од еден бекерел $(1 \mathrm{bq})$ значи дека просечно се одвива 1 распад за време од 1 секунда. Специфичната активност на ОУ е 14,8 Бq на мг споредено со 25,4 Бq на мг за природниот ураниум. Но, тука мора да се внимава на една замка при толкувањето на радиоактивноста. Имено, доколку во пресметката се вклучи и активноста на продуктите на распадот, тогаш вредноста на специфичната активност е повисока. Така, на пример, плутониумот (Пу-239) има многу повисока специфична активност од околу 2300000 Бq по мг додека гранитот има активност од 0,00005 до 0,0005 Бq по мг.

Во врска со употребата, се истакнува дека осиромашениот ураниум (OУ) е достапен материјал со ниска цена. Неговата висока специфична густина $(19,05$ г/цм3, која е 1,7 пати повеќе отколку на оловото - 11,35 г/цм3) и неговиот висок атомски број 3=92 обезбедува успешна можност за заштита од $\gamma$-радиација. Неговите карактеристики придонесуваат тој да биде една од можностите за обезбедување противтежа (балансирање) кај леталата ${ }^{1}$ и кај крстосувачките проектили ${ }^{2}$ каде што принудно не е можна употреба на материјали со помала густина. Позната е неговата употреба и како радијационен штит во производство на буриња за радиоактивен отпад во кои ке се чува потрошеното гориво од нуклераните рактори на поефикасен начин за околината. ${ }^{3}$ Тој, исто така, е високоуспешен материјал за изработка на воени оклопи кај кои ОУ се сместува во „ракавот” (меѓупростор) од вообичаениот челичен оклоп на тенкот каде што останува заробен. Можеби најконтроверзна е неговата употреба во противоклопната муниција. Кај оваа муниција површината од ОУ-пенетраторот се пали при судир (особено со челик), делумно се топи поради високата температура генерирана со ударот и релативно ниската точка на топење на ураниумот (со нагласка дека точката на топење му изнесува $1132{ }^{\circ} \mathrm{C}$ ), при што како што проектилот се топи така се изострува и го пробива тешкиот оклоп. ${ }^{4}$

Се тврди дека осиромашениот ураниум ги преплавил воените системи во светот и дека не постои земја која нешто значи на меѓународен план како воена сила, а притоа него да не го поседува во својот воен арсенал. Токму поради тоа што ваквите тврдења не се официјално потврдени (засега само САД ја признаваат употребата на осиромашен ураниум), се наметнува потребата од подетална анализа на „фамозноста“ на ОУ. Огромни количини ОУ во воените операции (во операцијата „Пустинска бура” приближно 305-340

\footnotetext{
' (Loewenstein P. 1989)

2 (Bleise, et al. 2003)

3 (Loewenstein P. 1989 )

${ }^{4}$ (Anderson et al. 1997; Peterson 1999)
} 
метрички тони, додека за операциите во Босна и во Југославија не постојат официјални податоци) (Peterson, 1999) беа расфрлани низ просторот, а од друга страна, не постои меѓународен закон, договор, регулатива, ниту, пак, обичај да се бара од корисникот на ОУ да го санира просторот на кој е употребено таквото оружје. Поради тоа што цената на ваквото чистење може да биде приближно и до стотици милијарди долари, а и поради тоа што каква било санација би подразбирала и признание за опасноста од ОУ, најверојатно, би се одбегнала таква санација. Јавната загриженост за ефектите врз околината од осиромашениот ураниум би можеле да направат муницијата со ОУ да биде политички неприфатлива и да резултира со забрана за употреба на ОУ-пенетратори. Извештаите од борбените дејства во кои била употребена ваквата муниција предупредуваат преку состојбата на бојните полиња и долготрајните ризици за здравјето кај месното население и воените ветерани дека можат да станат еден од главните проблеми за континуираната употреба на ОУ за воени цели.

Авторот чувствува потреба фактите за осиромашениот ураниум да бидат достапни за секого наспроти да се препуштаат на гласишта и прераскажувања. Трудот е обид да се проговори за вистината за ОУ. Затоа што доколку молчиме, може некој друг, некој кој за тоа „помалку" знае да ни ја открива тајната на (бес)последичната употреба на осиромашениот ураниум. Обидот е реализиран преку систематизација на податоците во три основни целини. Во првата се презентирани најзначајните каректеристики околу радиоактивноста на ураниумот и начините на пресметување на радиоактивноста. Втората целина површно ја обработува проблематиката на последичните биолошки ефекти на осиромашениот ураниум врз човековото тело и во него. Третиот дел, кој е во функција на поопсежен заклучок, има цел да даде едно поинакво видување кое ја опфаќа севкупната позитивна улога на осиромашениот ураниум и истовремено неговите негативни придружни влијанија, неговата контроверзна примена и иницијативите за активностите кои во иднина ќ ја следат неговата примена.

\section{2. Раяиоакйивносй на ураниумой}

\section{1. Прирояна раяиоакйивносй}

Ураниумот е најтешкиот елемент што се наоѓa во природата, со атомски број 3=92. Но, најтешките стабилни елементи што се наоѓаат во природата се неколку изотопи на олово со атомски број $3=82\left({ }^{204} \Pi б,{ }^{206} \Pi б,{ }^{207} \Pi б\right.$, и ${ }^{208} \Pi б$ застапени со $1,4 \%, 24,1 \%, 22,1 \%$ и $52,1 \%$ ) и еден изотоп на бизмут со атомски број $3=83$ ( $\left.{ }^{209} Б и\right)$. Со исклучок на првиот природен изотоп на оловото $\left({ }^{204} П б\right)$, сите други изотопи се со барем делумно радиогено потекло.

Сите природни елементи со атомски број 3>83 се радиоактивни. Овие елементи се распаѓаат со емисија на $\alpha$-честици (јадра на хелиум), или со емисија на негативни $\beta$ честички (електрони). И двата начина на радиоактивен распад може да бидат проследени со емисија на $\gamma$-зраци (енергетски фотони) ако јадрото потомок е во воздудена состојба. $\alpha$ емисијата го намалува атомскиот број 3 (бројот на протони) за 2 и масениот број А 
(вкупниот број протони и неутрони) за 4. Од друга страна, негативната $\beta$-емисија го зголемува атомскиот број 3 за 1 (со трансформирање еден неутрон од атомското јадро во протон), додека масениот број А останува константен. Како последица на ваквите распади, постојат 4 одвоени природни серии распад: ураниум, актиниум, ториум и нептуниум (види Табела 3).

\section{Табела 3: Серии раяиоакӣивен расйаg}

\begin{tabular}{|c|c|c|c|}
\hline Серија & Прв изотоп & $\begin{array}{c}\text { Полуживот } \\
\text { [год.] }\end{array}$ & $\begin{array}{c}\text { Последен } \\
\text { изотоп }\end{array}$ \\
\hline Ураниум & ${ }^{238} \mathrm{y}$ & $4.49 \times 10^{9}$ & ${ }^{206}$ Пб \\
\hline Актиниум & ${ }^{235} \mathrm{y}$ & $7.10 \times 10^{8}$ & ${ }^{207} \Pi б$ \\
\hline Ториум & ${ }^{232} \mathrm{Tx}$ & $1.39 \times 10^{10}$ & ${ }^{208} \Pi б$ \\
\hline Нептуниум & ${ }^{237} \mathrm{H}$ & $2.14 \times 10^{6}$ & ${ }^{209}$ Би \\
\hline
\end{tabular}

\section{2. Раяиоакииивни серии}

Три од овие радиоактивни серии распад се именувани по изотопот со најдолг полуживот. Серијата актиниум е именувана по еден од нејзините членови, со цел да се избегне постоење на две серии со идентично име. Само три од овие серии распад се наоѓаат во природата: ураниум, актиниум и ториум. Изотопот ${ }^{237}$ Нп има полуживот многу пократок отколку геолошката старост на Земјата, која изнесува околу 5 милијарди години, па така, целокупниот нептуниум се распаднал за време од првите 50 милиони години откако Земјата се формирала.

\section{3. Пресметување на раяиоактииностиа}

Активноста на дадено количество радиоактивен материјал се пресметува како константа на распад $\lambda$ (во релација со полуживот Т) мултиплицирана со бројот на радиоактивните јадра. Еден килограм чист радиоактивен изотоп со полуживот Т (сец) поседува активност $\mathrm{P}($ Бq/кг).

$$
\mathrm{R}=\lambda \frac{\mathrm{N}}{\mathrm{A}}=\frac{\ln 2}{\mathrm{~T}} \frac{\mathrm{N}}{\mathrm{A}}
$$

каде што $\mathrm{H}=6,023 \times 10^{23}$ кмол е Авогадровиот број, А (кг/кмол) е масениот број, лн2=0,693 и Т е полуживот во секунди. На пр. $\mathrm{A}=235$ кг/кмол за ${ }^{235} \mathrm{y}$ и

238 кг/кмол за 238 у. Единицата за активност е бекерел (1Бq=1распад/сец) или кири (1Ци $=3,7 \times 10^{10}$ Бq). 


\section{4. Акшивности на ураниумска руоа}

„Природниот ураниум содржи 99,274\% од У-238, 0,720\% од У-235 и $0,0055 \%$ од У234 ". Радиоактивноста на чистите изотопи У-238 и У- 235 е дадена во Табела 5. Во ураниумската руда У3О8 (кристална мешавина од УО2 и УО3 во 1:2 однос, позната како жолт колач), изотопот У-238 е во вечна рамнотежа со 14 други радиоактивни изотопи, секој имајќи иста активност како изотопот У-238, вклучувајќи го и радиогеничниот изотоп на ураниум У-234. Слично, изотопот У-235 е во вечна рамнотежа со 11 други радиоактивни изотопи. Затоа активноста на У-238 треба да се множи со фактор 15x (споредено со чистиот У-238) и активноста на У-235 со фактор 12х (споредено со чистиот У-235). Ако ја земеме предвид само $\alpha$-активноста, тогаш ги сметаме само $\alpha$-емитерите. Во овој случај, активноста на У-238 ке се мултиплицира со фактор 8х и активноста на У-235 со фактор од 7х (Табела 4).

Табела 4: Ураниумски серии во вечна рамнойежа

\begin{tabular}{|c|c|c|c|c|c|}
\hline \multicolumn{3}{|c|}{ Таб. 4 А: Ураниумска серија } & \multicolumn{3}{|c|}{ Таб. 4 Б: Ураниумска серија } \\
\hline Изотоп & Полу`ивот & Распад & Изотоп & Полу`ивот & Распад \\
\hline${ }^{238} \mathrm{y}$ & $4.49 \times 10^{9}$ години & $\alpha$ & $235 \mathrm{y}$ & $7.1 \times 10^{8}$ години & $\alpha$ \\
\hline${ }^{234} \mathrm{Tx}$ & 24.1 дена & $\square$ & ${ }^{231} \mathrm{Tx}$ & 25.5 часа & $\square$ \\
\hline${ }^{234 \mathrm{M}} \Pi \mathrm{a}$ & 1.17 минути & $\square$ & ${ }^{231} \Pi а$ & $3.25 \times 10^{4}$ години & $\alpha$ \\
\hline${ }^{234} \mathrm{y}$ & $2.48 \times 10^{5}$ години & $\alpha$ & ${ }^{227} \mathrm{AL}_{4}$ & 21.8 години & $\square$ \\
\hline${ }^{230} \mathrm{Tx}$ & 7.7×10 $0^{4}$ години & $\alpha$ & ${ }^{227} \mathrm{Tx}$ & 18.5 дена & $\alpha$ \\
\hline${ }^{226} \mathrm{~Pa}$ & 1600 години & $\alpha$ & ${ }^{223} \mathrm{~Pa}$ & 11.4 дена & $\alpha$ \\
\hline${ }^{222} \mathrm{PH}_{\mathrm{H}}$ & 3.82 дена & $\alpha$ & ${ }^{219} \mathrm{PH}_{\mathrm{H}}$ & 4.0 сец & $\alpha$ \\
\hline${ }^{218} \Pi о$ & 3.05 минути & $\alpha$ & ${ }^{215}$ По & 1.78 мсец & $\alpha$ \\
\hline${ }^{214} \Pi 6$ & 26.8 минути & $\square$ & ${ }^{211} \Pi 6$ & 36.1 минути & $\square$ \\
\hline${ }^{214}$ Би & 19.8 минути & $\square$ & ${ }^{211}$ Би & 2.13 минути & $\alpha$ \\
\hline${ }^{214} \Pi о$ & $162 \mu$ сец & $\alpha$ & ${ }^{207}$ Тл & 4.77 минути & $\square$ \\
\hline${ }^{210}$ Пб & 22.3 години & $\square$ & ${ }^{207} \Pi 6$ & Стабилен & \\
\hline${ }^{210}$ Би & 5.01 дена & $\square$ & & & \\
\hline${ }^{210} \Pi о$ & 138.4 дена & $\alpha$ & & & \\
\hline${ }^{206} \Pi 6$ & Стабилен & & & & \\
\hline
\end{tabular}

${ }^{5}$ (Horen D. J. et al. 1973) 


\section{5. Акйивностй на йрирояниот ураниум}

Во процесот на извлекување на ураниумот од рудата (сите 3 изотопи) сите радиоактивни потомци во двете радиоактивни серии распад се елиминирани (со исклучок на радиогениот изотоп У-234). Нова временска рамнотежа се воспоставува во период од неколку месеци помеѓу У-238 и два други радиоактивни продукта (Тх-234 и Па-234м). Вечната рамнотежа помеѓу ураниумските изотопи У-238 и У-234 не е нарушена со процесот на екстракција. Слично, нова вечна рамнотежа е воспоставена во период од неколку дена помеѓ У У-235 и еден радиоактивен продукт потомок, Тх-231. Затоа активноста на У-238 по екстракцијата треба да се помножи со фактор 4x а активноста на У-235 со фактор 2х. Ако нѐ интересира само $\alpha$-активност, активноста на У-238 ќе се множи со фактор $2 \mathrm{x}$ a активноста на У-235 останува непроменета.

\section{Табела 5: Сйецифична актиивносй на ураниумот̆}

\begin{tabular}{|c|c|c|c|c|}
\hline Ураниум & $\begin{array}{c}\text { Активност } \\
\text { [МБq/кг] }\end{array}$ & $\begin{array}{c}\alpha \text {-активност } \\
{[\mathrm{MБq} / \kappa г]}\end{array}$ & $\begin{array}{c}\text { Активност } \\
\text { [мЦи/кг] }\end{array}$ & $\begin{array}{c}\alpha \text {-активност } \\
{[\text { мЦи/кг }]}\end{array}$ \\
\hline $238 \mathrm{y}$ & 12.4 & 12.4 & 0.335 & 0.335 \\
\hline $235 \mathrm{y}$ & 78.4 & 78.4 & 2.12 & 2.12 \\
\hline $\begin{array}{l}\text { Природен ураниум } \\
\text { со своите потомци }\end{array}$ & 50.4 & 25.2 & 1.36 & 0.681 \\
\hline $\begin{array}{c}\text { Осиромашен ураниум } \\
\text { со своите потомци }\end{array}$ & 39.3 & 14.4 & 1.06 & 0.389 \\
\hline Модерно олово & $660 \times 10^{-6}$ & $220 \times 10^{-6}$ & $18 \times 10^{-6}$ & $6 \times 10^{-6}$ \\
\hline
\end{tabular}

\section{6. Активност на ОУ}

Радиогениот изотоп У-234 се извлекува во процесот на збогатување со иста таква ефикасност како и фисибилниот изотоп У-235. „Ова е демонстрирано со радиоактивноста на збогатениот ураниум до степен на оружје $\left(47 \mathrm{MЦи/кг)".}{ }^{6}\right.$ Како комбинираната $\alpha$ активност од 90\% У-235 и 10\% У-238 е само 1.95 мЦи/кг, незначителното количество У-234 е објаснување за останатата $\alpha$-активност на збогатениот материјал од 45мЦи/кг. Факторот на збогатување за У-235 е добиен како однос од содржината на У-235 во збогатениот и природниот ураниум $(90 / 0,72=125 \mathrm{x})$, додека факторот на збогатување за У-234 е добиен како однос од У-234 $\alpha$-активност $(45 / 0,335=135 \mathrm{x})$. Различни извори ја наведуваат

${ }^{6}$ (Harley H. et al. 1999) 
содржината на У-234 помеѓу $0,0005-0,002 \%$ во осиромашениот ураниум со содржина на У235 помеѓ $0,2-0,3 \%$, соодветно на 9-36\% од оригиналниот У-234 во природниот ураниум. ${ }^{7}$ Земајќ ја предвид важноста на содржината на У-234 за утврдување на активноста на осиромашениот ураниум, овој број е прилично непрецизен.

Поради тоа што збогатувањето на У-235 зависи единствено од разликата на масениот број ДА=238-235=3кг/кмол, разумна процена на содржината У-235 во ОУ може да се направи од разликата на маса ДА=238-234=4кг/кмол. Ако во повеќефазниот процес на збогатување е осиромашен до $28 \%$ од неговата оригинална содржина, У-234 би требало да се осиромаши до $0,28(4 / 3)=18 \%$ од неговата оригинална содржина, оставајќи $0,001 \%$ од У234 во ОУ.

Крајните пресметки што се однесуваат на специфичната активност на ураниумот (Табела 4) укажуваат дека вкупната активност на ОУ е $22 \%$ помала, а $\alpha$-активноста $43 \%$ помала во споредба со природната мешавина на ураниумските изотопи, примарно поради пониската содржина на радиогениот изотоп У-234. Ова е причината за често објавувани тврдења дека ОУ е за околу $40 \%$ помалку радиактивен отколку природниот. Осиромашувањето само од изотопот У-235 ја намалува вредноста за 1,6\% и во тоталната и во $\alpha$-активноста.

„Објавени се некои смешни тврдења што ја споредуваат радиоактивноста на ОУ со вообичаената заднинска радиоактивност на оловото". ${ }^{8}$ Од овие причини вкупната заднинска и $\alpha$-активност на модерното оловото, исто така, е дадена во Табела 4. „Оваа радиоактивност речиси целосно се должи на контаминацијата од Пб-210 заедно со неговите продуктипотомци Би-210 и По-210". 9 Поради тоа што радиоактивноста на комерцијалното олово не е со суштински карактеристики (како за ураниумот), зависи од набавувачот, вредностите во Табела 4 се типични. Старото и средовечното олово може да биде за неколку нивоа од магнитуда помалку радиоактивно отколку модерното олово, бидејќ Пб-210 е со полуживот $\mathrm{T}=22,3$ години, кој е многу помал во споредба со неколку века (или милениуми). Но, и покрај тоа, вкупната радиоактивност на ОУ е за околу 60.000 пати повисока отколку вкупната радиоактивност на модерното олово, а неговата $\alpha$-активност е за 65.000 пати повисока.

\section{3. Биолошки ефекий на ОУ}

Испорачаната доза на јонизирачкото зрачење во Меѓународниот систем на единици (СИ) се изразува во сиверти (Св). Сивертот е мерка за здравствените ефекти на ниските нивоа на јонизирачкото зрачење врз/на човечкото тело. Количините што се мерат во сиверти имаат цел да покажат на стохастичките ризици за здравјето, кои за процена на радијациската доза се дефинирани како веројатност за појава на рак и генетско

\footnotetext{
${ }^{7}$ (Bukowski G. e t al. 1993)

${ }^{8}$ (Bacon 1998).

"(Alessandrello A. Et al. 1998).
} 
оштетување. ${ }^{10}$ Сивертот се употребува за количини радијациски дози како што се еквивалентна доза, ефективна доза и посветена доза. Тој се користи за означување на ризикот од ефектот на надворешно зрачење од изворите надвор од телото, како и за ефектот на внатрешно зрачење од вдишани или проголтани радиоактивни супстанции. Вообичаено, сивертот не се употребува за високи нивоа на зрачење што произведуваат детерминистички ефект, кој е сериозно или акутно оштетување на ткивото кое неизбежно ќе се случи. Овие ефекти се споредливи со физичкиот квантитет на апсорбираната доза мерена со единицата греј (Гу). ${ }^{11} 1$ Гу=1 јоул/кг и претставува физички квантитет на депозит на еден јул од радијациска енергија во 1 кг материја или ткиво. Исто така, и 1 Св=1 јоул/кг но тој е мерка за биолошкиот ефект, преставувајќки еквивалент на биолошкиот ефект на депозитот од 1 јул радијациска енергија во 1 килограм човечко ткиво.

За да се овозможи разгледувањето на стохастичкиот ризик за здравјето, направени се пресметки за претворање на физичкиот квантитет на апсорбираната доза во еквивалентна и ефективна доза, детали што зависат од типот на зрачење и билошкиот контекст. За примена во заштитата од зрачење и дозиметриска процена Меѓународната комисија за радиолошка заштита (International Commission on Radiological Protection - ICRP) и Меѓународната комисија за радијациски единици и мерки (International Commission on Radiation Units and Measurements - ICRU) имаат објавено препораки и податоци што се употребуваат за пресметување на овие. Така, еден сиверт (1 Св) е со 5,5 \% шанса за евентуално развивање на рак. ${ }^{12}$ Дози поголеми од 1 сиверт примени за кратко време, најверојатно, ќе предизвикаат радијациско труење, кое веројатно ќе доведе до смрт за неколку недели.

\section{1. Условеносй на йослеоичнитие ефекйи на ОУ}

Повеќе фактори ги детерминираат потенцијалните последични ефекти од ОУ, во зависност од тоа дали дејствувањето на ОУ е надворешно (надвор од телото) или внатрешено (внатре во телото).

\subsection{1. Наявор оя йелойо}

Кога ОУ е надвор од телото, потенцијалните ефекти се лимитирани само на радиацијата, а не и на хемиската токсичност. Изложеноста на зрачењето зависи од тоа во колкава количина ОУ е присутен, колку е блиску до телото и колку долго е тој присутен. Сето тоа ги релативизира пресметките за изложеноста и процена на ефектите. Како што веќе претходно беше изнесено, ОУ емитува три типа јонизирачко зрачење, алфа-честици, бета-честици и фотони (х-зраци и $\gamma$-зраци). За да се долови ефектот, ќ се наведат

\footnotetext{
${ }^{10} \mathrm{ICPR}$ истакнува дека во опсегот на ниски дози под $100 \mathrm{mSv}$, научно е веродостојно да се претпостави дека наклонетоста кон рак или наследни ефекти ке се зголеми во директна пропорција со зголемувањето на еквивалнетната доза во погодените органи и ткива. Види ICRP publication 103 para 64.

"ICRP report 103 para 104

${ }^{12}$ ICRP report 103 para 105
} 
едноставни примери. Така, алфа-честиците (јадра од атоми на хелиум) ги запира лист хартија, и во нашиов случај повеќето би биле запрени од надворешниот слој на кожата. Бета-честиците (забрзани електрони) можат да навлезат до 1 см во телото. Додека, пак, третата група, фотоните, имаат голема способност за пенетрација и можат да поминат низ телото.

Радијациската доза за кожата, која доаѓ, главно, од бета-честиците, може да достигне до 2-5 мСв (милисиверти ) на час, доколку се држи грутка ОУ во раката. Тоа лесно може да биде редуцирано со носење ракавици, или ако ОУ е затворен во некој друг материјал. Понатаму, кожата е релативно нечувствителна на радиација, така што дури и постојан контакт (чување парче в џеб или негово носење како накит) не е веројатно дека би предизвикал радијациски изгореници или други брзи ефекти. Такви ефекти побаруваат дози од неколку илјада мСв, испорачани за кратко време, но со 2-5 мСв на час ОУ би требало да дејствува со месеци за да предизвика такви ефекти. Во секој случај, би можело да се очекува мал ризик од рак на кожата.

Теоретскиот максимум за целото тело озрачено со $\gamma$ надворешна доза, за некого што е опкружен со ОУ, пресметан е на 0,025 мСв на час $(0,6$ мСв на ден). Највисоките експозиции што би можеле да достигнат во практика се во возилата што имаат оклоп од ОУ и што носат муниција од ОУ. Според мерењата на Армијата на САД, доза зрачење за целото тело во тенк целосно опремен со ОУ е помала од 0,002 мСв на час. Така, на пример, управување со тенк околу 1.000 часа резултира со прием на доза слична на просечната годишна доза од природното зрачење во Обединетото Кралство. Ваквите изложувања се редовно мерени и контролирани. ${ }^{13}$

\section{2. Внайре во йелойо}

Доколку ОУ навлезе во телото, потенцијално може да предизвика оштетување (внатрешна изложеност) и од зрачењето и од хемиското дејство. Во телото може да навлезе преку инхалација (вдишување ситен прав), ингестија преку устата, контаминација на отворена рана или на боево поле ако телото е погодено со парчиња од ОУ-гранати.

Вдишаните ОУ-честички може да навлезат во телото преку носот и/или устата. Во зависно од нивната величина, некои честици ќе бидат издишани, некои ке се задржат во горните дишни патишта (носот, устата, бронхите), а некои ке допрат до белите дробови. Повеќето честици поголеми од неколку микрометри ( $\mu$ м) во дијаметар се филтрираат во повисоките дишни патишта и така не можат да стигнат во белите дробови (на пример, носот е прилично ефективен филтер). Колку за споредба, клетките од кои е составено телото се околу $10 \mu \mathrm{м}$ во пречник. Повеќето честици што се депонирани во повисоките горни патишта се фатени од лигата која се лачи во грлото и се голтаат за време од неколку часа. Повеќето честици што се депонирани во белите дробови брзо се заробуваат од мобилни клетки наречени макрофаги, прилично слични на крвните клетки. Тие можат да ги пренесат до бронхијалното стебло, да ги однесат со лигата и да бидат проголтани, но тоа е долг процес и некои честички можат да останат во белите дробови со години. Мал дел од

${ }^{13}$ (Fetter \& Hippel 1999, 129) 
честиците депонирани во белите дробови ќе се префрлат до лимфните јазли, каде што, најверојатно, ќе останат доколку не се разложат. Било во белите дробови било во лимфните јазли, честиците на ураниум оксид етапно ќе бидат разложени, а потоа апсорбирани во крвта. Дури и материјата која се води како нерастворлива ќе се разложи до одреден степен во белите дробови: честиците кои се доволно мали да бидат депонирани имаат голема површина по единица маса на која дејствува течноста во клетките.

Откриено е дека од вдишаниот прав што е наталожен во белите дробови, еден дел веднаш се разложува, а остатокот на одредени периоди. Извршувани се тестови со оксиди на ОУ при симулација на разложување во белите дробови. Тие покажале дека од честиците што се формирани кога се загревани грутки од ОУ, неколку проценти од нив се разложуваат веднаш, а остатокот многу бавно. За честици што се формирани кога пенетратор од ОУ ќе удри во парче оклоп, поголем дел, околу $25 \%$, се разложува брзо. Други тестови покажале дека и во двете ситуации честиците се состојат, главно, од два типа ураниум оксид (У3О8 и малку УО2), при што и двата се релативно нерастворливи. Индустриски експерименти со овие оксиди индинцираат на долг период на дисолуција во белите дробови од околу $0,1 \%$ за ден. ${ }^{14}$

Кога постои ингестија на ураниумски состојки, ураниумот не се апсорбира веднаш во крвта од утробата. Дури и за растворливи форми од ураниум само неколку проценти се апсорбирани. За ураниумови оксиди формирани од ОУ при удар или оган, процентот, најверојатно, би бил помал. За релативно нерастворливи состојки како што се горенаведените два оксида се наведува вредност од $0,2 \%$.

Повеќето од ураниумот апсорбиран во крвта брзо се излачува, главно со урината. Околу $65 \%$ се излачува за време на првиот ден и други $10 \%$ за време на првата недела. Потоа следува континуирано излачување, од околу $0,002 \%$ (од вкупната количина во крвта) од ден за една година. Тоа е и причината зошто се прават често контроли на урината при утврдување на количината на ураниум во телото. Ураниумот што нема да се исфрли веднаш се складира во различни органи. Околу $10 \%$ се складира во бубрезите. Бидејќи бубрезите се релативно мали (околу 300 гр кај возрасни лица), концентрацијата ќе биде повисока отколку кај другите органи. Но, и ураниумот кој е складиран во бубрезите таму не останува за долго. За три месеци, количеството се сведува на околу $0,1 \%$ од вкупната количина на почетокот која била внесена во крвта. Околу $15 \%$ се складира во коските, но бидејќи нивната маса (5.000 гр) е многу поголема од онаа на бубрезите, концентрацијата е пониска. Ураниумот останува многу подолго во коските, така што неколу проценти ке бидат задржани и по пет години и околу $1 \%$ по 25 години. ${ }^{15}$

\section{4. Намесйо заклучок: еуно йоинакво вияување за осиромашениой ураниум}

Ураниумот е многу тежок (густ) метал кој може да се искористи како обилен извор на концентрирана енергија. Невообичаен за сончевиот систем, денес неговиот радиоактивен

${ }_{14}$ (Public Health England 2007)
${ }^{15}$ (Public Health England 2007) 
распад обезбедува главен извор на топлина во внатрешноста на земјата, предизвикувајќ конвенкција и поместување на континентите.

Најсериозен ризик за здравјето поврзан со ископувањето на ураниумот е рак на белите дробови како последица на инхалација на продуктите од распадот на ураниумот. Остатоците од рафинирањето на ураниумот содржат радиоактивни материјали како што е радиум-226 и тешки метали (на пример, манган, молибден) кои можат да допрат до подземните води. Во близина на отпадоците, примероците од вода покажуваат контаминација поголема за сто пати од онаа што е прифатлива за водата за пиење.

Ураниумот е главно гориво за нуклеарни реактори и основен материјал за нуклеарно оружје. Со цел да се одржи верижна реакција на нуклеарна фисија, ураниумот треба да се збогати со фисибилниот изотоп У-235 до степен за реактор 3,2-3,6\% или степен за оружје $(90 \%+)$. Овој процес не само што продуцира збогатен продукт туку, исто така, и отпад осиромашен од У-235 до 0,3\%. (Нуклеарно регулаторната комисија - (Nuclear Regulatory Commission - NRC) го дефинира осиромашениот ураниум како ураниум во кој содржината на изотопот У-235 е помала отколку $0,72 \%$ ).

За да се збогати ураниумот, мора прво да се доведе во хемиска форма на ураниум хексафлуорид (УФ6). По збогатувањето, УФ6 хемиски се претвора до ураниум диоксид или метал. Ураниумот, кој се употребува, главно, во реакторите, е во форма на ураниум диоксид (УО2) или ураниумски метал, додека нуклеарните оружја ја користат единствено металната форма. Најголемиот ризик и во процесот на претворање и во процесот на збогатување на ураниумот доаѓ од справувањето со ураниум хексафлуорид, кој е и хемиски токсичен и радиоактивен. Згора на тоа; тој реагира со влага, при што се ослободува високо токсична хидрофлуреста киселина. Постројките за претворање и збогатување бележат бројни акциденти врзани со УФ6. Процесот на збогатување може да биде и реверзибилен. Високо збогатениот ураниум може да биде разреден или помешан со осиромашениот, со природниот или ниско збогатен ураниум за да се продуцира од 3 до 5\% пониско збогатено реакторско гориво. Ураниумскиот метал при различни збогатувања може да биде хемиски процесиран, по што може да се помеша со хомогени материјали на одредено збогатено ниво. Резултатите од ризикот за здравјето и околината се слични со оние од процесот на претворање и збогатување. УФ6 е високо реактивен со вода, при што формира течни продукти како што се уранил флуорид (УО2Ф2) и хидроген флуорид (ХФ), и двата токсични. Надворешниот контакт со ХФ резултира со хемиски изгореници на кожата, а изложувањето на дисперзирани честици на ХФ предизвикува оштетување на очите, носот и грлото.

Осиромашениот ураниум (У-238) се распаѓа многу бавно, неговиот полуживот е ист колку и староста на земјата. Тоа значи дека е практично неуништлив. Иако е едвај радиоактивен, помалку отколку многу други изотопи во карпите и песокот, сепак, тој генерира енергија (кинетичка топлина) од 0,1 waт/тон што е доволно да ја загрее Земјината кора. Ураниум-238 емитира алфа-честички кои потешко пенетрираат во материјата во споредба со останатите форми на зрачење, и слаби гама-зраци. Сѐ додека останува надвор од телото, ураниумот поседува мал ризик за здравјето (главно, од гама-зраците). Ако е вдишан или внесен во дигестивниот систем, неговата радиоактивност носи зголемен ризик 
од рак на белите дробови и на коските. Ураниумот во високи концетрации, исто така, е хемиски токсичен и може да предизвика оштетувања на внатрешните органи, особено на бубрезите. Студиите за животните укажуваат дека ураниумот може да влијае врз репродукцијата, врз фетусот во развој, и да го зголеми ризикот од леукемија и рак на мекото ткиво.

ОУ денес е предмет на бројни расправи за неговата употреба и чување. Од постоењето на регулативи и забрани, нивно засилување со формирање бројни комисии, започнати или предложени мерки за заштита од штетните влијанија на ОУ производни капацитети и полигони за тестирање во минатото и во сегашноста и од неодамнешните ограничувања на тестирање на муницијата од ОУ, евидентно е дека владите и воените власти се свесни дека проширената употреба на ОУ е штетна и за луѓето и за околината. Тие, исто така, се свесни за фактот дека радиоактивноста на ОУ е доволна да услови отстранување на контаминираните објекти, вклучувајќ ја и земјата од просторите за производство на ОУ и полигоните за негово тестирање.

Поради општата вознемиреност со која многу луѓе гледаат на овој проблем, радиолошките и токсиколошките карактеристики на ОУ треба да заземат свое место во тренингот и едукацијата кај оружените сили и цивилите, како еден од начините да се намалат можностите за каков било ризик. ${ }^{16}$ Бидејќк муницијата од ОУ е достапна до многу нации, можно е да се очекува контаминацијата да се прошири на сите идни борбени простори. Оттаму, знаењето, експертизата и опремата за спречување или ублажување на изложеноста мора да бидат еднакво распространети.

${ }^{16}$ (US Army Combat readiness/Safety Center 2010) 


\section{Литерапиура}

Alessandrello A., Arpesella C., Brofferio C., Bucci C., Cattadori C., Cremonesi O., Fiorini E., Giuliani A., Latorre S., Nucciotti A., Orvini E., Pavan M., Parmeggiano S., Perego M., Pessina G., Pirro S., Previtali E., Romualdi B., Rotilio A., Tatananni E., and Zanotti L. 1998, 'Measurements of Internal Radioactive Contamination in Samples of Roman Lead to Be Used in Experiments on Rare Events', Nuclear Instruments and Methods in Physics Research B142, pp. 163-172.

Anderson M., Enyeart T. D., Jackson T. L., Smith R. W., Stewart C. E., Thompson R. A., Ulick M. D., and Zander K. K. 1997. Resumption of Use of Depleted Uranium Rounds at Nellis Air Force Range. Target 63-10; US Air Force.

Bacon K. H. 1998, DoD News Briefing. (December, 3)

Bleise, Danesi P.R., and W. Burkart. 2003. 'Properties, use and health effects of depleted uranium (DU): a general overview', Journal of Environmental Radioactivity 64: 93-112

Bukowski G., Lopez D. A., and McGehee F. M. III 1993, 'Uranium Battlefields Home \& Abroad: Depleted Uranium Use by the US Department of Defense', Rural Alliance for Military Accountability. Progressive Alliance for Community Empowerment, Citizen Alert

Fetter S. \& Hippel von F. N., 1999, 'The Hazard Posed by Depleted Uranium Munitions',Science \& Global Security, Volume 8:2, pp.125-161

Harley H., Foulkes E. C., Hilborne L. H., Hudson A., and Anthony C. R., 1999, 'Depleted Uranium', A Review of the Scientific Literature As it Pertains to Gulf War Illnesses, Vol. 7.pn. 2-5. Available from: MR-1018/7-OSD; RAND (September 2014)

Horen D. J. et al, 1973, Nuclear Level Schemes $A=45$ through $A=257$ from Nuclear Data Sheets; Academic Press, New York and London.

ICRP, 2007. The 2007 Recommendations of the International Commission on Radiological Protection. ICRP Publication 103. Ann. ICRP 37 (2-4).

ICRP, 2007. The 2007 Recommendations of the International Commission on Radiological Protection. ICRP Publication 103. Ann. ICRP 37 (2-4). Available from: $<$ http://www.icrp.org/docs/ICRP_Publication_103-Annals_of_the_ICRP_37(2-4)-

Free_extract.pdf $>$ [05.05.2015]

Loewenstein P. 1989. "Industrial Uses of Depleted Uranium". In American Society for Metals, Vol. I.

Peterson S. 1999. The trail of a bullet - Will America risk use of DU in Kosovo? - DU's global spread spurs debate over effect on humans - A rare visit to Iraq's radioactive battlefield DU's fallout in Iraq and Kuwait: a rise in illness?; A Special Report: Christian Science Monitor.

Public Health England, Radiation, Health protection and Public Health 2007, Depleted Uranium $(D U)$ : general information and toxicology, Government of UK. Available from: < https:/www.gov.uk/depleted-uranium-du-general-information-and-toxicology $>$. [01 April 2015]

US Army Combat readiness/ Safety Center. 2010. "TVT 3-120 Tier I Depleted Uranium (DU) General Awareness Training". Available from: 
<https:/safety.army.mil/multimedia/VIDEOLIBRARY/VideoPlaver/Tabld/421/Videold/ 342/TVT-3120-Tier-I-Depleted-Uranium-DU-General-Awareness-Training.aspx > [May 1 2015] 


\section{Sergej CVETKOVSKI}

\section{THE TRUTH ABOUT DEPLETED URANIUM}

\section{Summary}

Depleted uranium (U-238) decays very slowly, with its half-life same as the age of the earth. This means that it is virtually indestructible. Although it is barely radioactive, less than many other isotopes in rocks and sand, it does generate energy (in form of kinetic heat) of 0,1 watt /ton which is enough to warm the Earth's crust. Uranium238 emits alpha particles which penetrates the material more difficult compared with other forms of radiation and also weak gamma rays. As long as it remains outside the body, the uranium poses a small health risk (caused mainly by gamma rays). If it is inhaled or added to the digestive system, its radiation carries an increased risk of lung cancer and bone cancer. Uranium in high concentrations is also chemically toxic and can cause damage to internal organs, especially the kidneys. Animal studies alert that uranium may affect reproduction, the developing fetus, and may increase the risk of leukemia and of the soft tissue cancer.

DU at the present is a subject of numerous discussions on its use and storage. Since the existence of regulations and prohibitions, their amplification by creation of numerous commissions, since initiated or proposed measures of protection against the harmful effects of DU's production facilities and test ranges in the past as well as the present, and since (not so) recent restrictions on testing of DU ammunition, it is evident that governments and military authorities are aware that the expanded use of DU is harmful both to people and the environment. They are also aware of the fact that the DU radioactivity is sufficient to condition the removal of contaminated facilities, including country soil from DU production areas and testing polygons.

Because of the general anxiety by which many people look upon this problem, the radiological and the toxicological characteristics of DU should take own place in the training and education of the armed forces and civilians, as a way of reducement of any risk possibilities. Because DU ammunition is available to many nations, it is likely to expect contamination being spread to all future combat areas. Hence, the knowledge, the expertise and the equipment for prevention or mitigation of exposure must be equally distributed.

Keywords: DEPLETED URANIUM, ISOTOPES, INFLUENCE, RADIATION, TOXICITY, DOSE 